\begin{tabular}{llllllll}
$\mathbf{A}$ & $\mathbf{R}$ & $\mathbf{T}$ & $\mathbf{Y}$ & $\mathbf{K}$ & $\mathbf{U}$ & $\mathbf{L}$ & $\mathbf{Y}$ \\
\hline$-10-1$
\end{tabular}

ROCZNIKI TEOLOGICZNE

Tom LXVIII, zeszyt 5 - 2021

DOI: http://dx.doi.org/10.18290/rt.21685-1

\title{
KONIECZNOŚĆ ZACHOWANIA ZWIĄZKU TEOLOGII I WIARY Z HISTORIĄ W DUCHU SOBORU WATYKAŃSKIEGO II
}

\author{
THE NECESSITY OF PRESERVING THE RELATIONSHIP \\ OF THEOLOGY AND FAITH \\ WITH HISTORY IN THE SPIRIT OF THE SECOND VATICAN COUNCIL
}

\begin{abstract}
A b s t r a c t. This article points out the necessity of preservation of a relationship of faith and history and necessity of profounding such relationship as of today because some factors from the past (rationalism, neo-scholasticism) weaken it and some contemporary tendencies (postmodernism, abstract theology, religious relativism) undermine its meaning. The author comes from the relationship of theology and faith with the history of salvation in antiquity, indicates its weakening in the Middle Ages, breaking it up in the Age of Enlightenment and rediscovering its validity again in the early twentieth century. Analyzing the Constitution on God's Revelation (Dei Verbum) makes more familiar the exegesis of faith contained in it (fides quae and fides qua) as a response to the historical revelation of God in history.Taking into consideration the new post-conciliar theological and pastoral challenges, he emphasizes the importance of preserving an internal relationship of theology and faith with history for shaping the latter one through human activity corresponding to the common good and the realization of the final vocation. He points to the possibility of shaping history in connection with the mystery of the salvific embodiment and the dialectic contained in it, and then explains the eschatological way of fulfilling the creation and his relationship with involvement in worldliness.
\end{abstract}

Keywords: God's revelation; faith; the history of salvation; the laicization of history; temporal commitment; progress; the dialectic of action; the fruits of efforts.

Dr hab. Stanisław T. ZARZYCKI SAC - Katedra Historii Duchowości, Instytut Nauk Teologicznych, Katolicki Uniwersytet Lubelski Jana Pawła II; adres do korespondencji: Al. Racławickie 14, 20-950 Lublin; e-mail: szarzycki@kul.pl; ORCID: https://orcid.org/0000-0002-1566-6695. 
Akcent na historyczność wiary nienaruszającą depozytu wiary jest jedną z podstawowych cech nauki Soboru Watykańskiego II (KDK 62) ${ }^{1}$. Kościół ma charakter historyczny i powinien w każdej epoce historii głosić wiarę w Chrystusa w sposób zrozumiały i dostosowany do mentalności ludzi. Dlatego też wśród propozycji kolejnych recepcji tegoż Soboru wskazuje się zarówno na potrzebę odczytywania jego litery, nauki, by pozostać wiernym substancji wiary, jak i ducha Soboru, czyli doświadczenia przez jego uczestników bliskości Boga wobec Kościoła i świata dzisiajª i będącej niejako przedłużeniem tego doświadczenia tożsamości historycznej wiernych. W czym wyraża się historyczny wymiar wiary katolickiej, ukazanej od strony biblijnej i teologicznej w Konstytucji dogmatycznej o Objawieniu Bożym i w jej pastoralnym ukierunkowaniu w Konstytucji duszpasterskiej o Kościele w świecie wspótczesnym? Czy ów historyczny wymiar wiary ma znaczenie dla głębszego rozumienia teologii i wiary w Jezusa Chrystusa, zmartwychwstałego Pana historii ożywianej przez Jego Ducha oraz dla nowego sposobu kształtowania historii osobistej i społecznej oraz dla spełnienia się człowieka? Czy soborowa i posoborowa nauka potwierdza tezę Balthasara, że „im bardziej w teologii odsłania się historyczność, tym bardziej rozwija się sama teologia"3? Potwierdzenie tej tezy jest istotne dla wszystkich dyscyplin teologicznych będących w służbie wierze tak poszczególnego chrześcijanina jak i całego Kościoła.

\section{TEOLOGIA I WIARA CHRZEŚCIJAŃSKA A HISTORIA - WPROWADZENIE HISTORYCZNE}

O historycznym wymiarze wiary można mówić jedynie w ramach historii świata, w której rozgrywa się historia zbawienia. Współczesne zsekularyzowane pojęcie historii upatruje podstawę historii w człowieku, w jego istocie, biblijne jej rozumienie sytuuje ją w Bogu. W języku polskim termin „historia" ma dwojakie znaczenie: 1) podmiotowe, obejmujące: a) wiedzę opartą na oglądaniu i poznawaniu wydarzeń, ludzi i rzeczy; b) naukę o dziejach czło-

\footnotetext{
${ }^{1}$ Por. także Jan XXIII, „Gaudete Mater Ecclesia. Przemówienie wygłoszone w dniu otwarcia Soboru Watykańskiego II" (11 X 1962), w Andrzej Michalik, Odkryć Sobór. Szkic historyczno-teologiczny Soboru Watykańskiego II (Tarnów: Wydawnictwo BIBLOS, 2006), 126.

${ }^{2}$ Michel Fédou, „Le Concile Vatican II: un enjeu d'interpretation”, w Vatican II sous le regard des historiens, red. Ch. Theobald, 149-153 (Médiasèvres, 2006).

${ }^{3}$ Hans Urs von Balthasar, Burzenie bastionów, tłum. J. Zakrzewski (Kraków: Wydawnictwo WAM, 2000), 14.
} 
wieka w czasie i przestrzeni (od XIX w.); 2) przedmiotowe, oznaczajace: a) wiedzę opartą na widzeniu faktów; b) „dzieje”, czyli to, co się dzieje w określonym czasie i przestrzeni, wydarzenia, czyny ${ }^{4}$.

Historia zbawienia, choć w dokumentach Kościoła jest o niej mowa dopiero na Soborze Watykańskim II (KL 16; KDK 16. 41; KO 2), nie jest czymś nowym, gdyż nauczano o niej wcześniej w kazaniach, na katechezie itp. Wcześniej jednakże zbawienie rozumiano jako coś pozahistorycznego, a drogę do świętości pojmowano w znacznej opozycji do świata i wybierano ucieczkę od niego (fuga mundi) i tego, co się w nim działo. Wyrażenie ,historia zbawienia" jest kategorią biblijno-teologiczną i oznacza działanie Boga wobec człowieka mające charakter progresywnego objawienia mu siebie samego i swego zbawczego planu realizowanego w ramach historii świata - nierzadko nawet wbrew tendencjom w nim panującym - według kategorii: obietnica i spełnienie, i w określonym następstwie wydarzeń: grzech pierworodny, powołanie ojców, wyjście z Egiptu, zawarcie przymierza, objęcie w posiadanie ziemi, wcielenie Słowa, krzyż i zmartwychwstanie Jezusa Chrystusa, ustanowienie Kościoła, ponowne przyjście Zmartwychwstałego ${ }^{5}$.

Podobnie jak historia świata, także historia zbawienia może być rozpatrywana: a) od strony podmiotowej, czyli od strony przekazu, słowa Bożego o zbawieniu, opowiadania biblijnego, relacji historycznej, nauki teologicznej; b) od strony przedmiotowej, czyli „dziejów zbawienia”, na które składają się czyny Chrystusa, dzieła Ducha Świętego, wydarzenia zbawcze i sakramentalne, odkupienie, usprawiedliwienie itp. Bartnik, jako zwolennik historii personalistycznej, dodaje do tego postulat ,wyższej syntezy” wymiaru podmiotowego i przedmiotowego dokonującej się w osobie ludzkiej możliwej do uzyskania dzięki Jezusowi Chrystusowi, tak iż cały człowiek staje się ,historią zbawczą" i „dziejami zbawienia".

${ }^{4}$ Czesław Stanisław Bartnik, Historia ludzka i Chrystus. Szkice z chrześcijańskiej wizji dziejów (Katowice: Księgarnia św. Jacka, 1987), 7-8. Termin „dzieje” pochodzi od Ł. Górnickiego (XVI w.). Odpowiada niem. terminowi Geschichte (w odróżnieniu od Historie - obietywne dokumentowanie faktów z przeszłości, nauka o nich), oznaczającemu ,polityczny, kulturowy i społeczny przebieg procesu rozwoju określonego zakresu geograficznego lub kulturowego", jak również wydarzenia, które do niego przynależą, DUDEN Deutsches Universalwörterbuch, hrsg G. Drosdowski i in., Dudenverlag (Mannheim-Wien-Zürich: Dudenverlag, 1983), 485.

${ }^{5}$ Paul Hubert Schünglel, Historia zbawienia, w Praktyczny stownik biblijny, red. A. Grabner-Haider (Warszawa: Instytut Wydawniczy PAX; Wydawnictwo Księzy Pallotynów, 1994), 443-445.

${ }^{6}$ Czesław Stanisław Bartnik, Chrystus jako sens historii (Wrocław: Wydawnictwo Wrocławskiej Księgarni Archidiecezjalnej, 1987), 122-123. 
Teologia od początku widziała w Logosie Wcielonym podstawowe założenie prawdy w sensie kosmologicznym i metafizycznym. Augustyńskie Państwo Boże uznawano za dogmatyczny wykład prawdy - raz objawionej i ustalonej - głoszonej w historii świeckiej podporządkowanej Bogu jako jej Panu i historii świętej, tj. historii będącej serią aktów wiary w Opatrzność Bożą porządkująca dzieje człowieka i przekraczającą je, ku temu, by wierni - po urzeczywistnieniu przez Kościół jego posłannictwa - mogli być doprowadzeni do pozadoczesnego celu - zbawienia ${ }^{7}$. Tryumf „,państwa Bożego” nad „państwem ziemskim”, miłości Bożej nad miłością własną zależy, według Augustyna, od zwycięstwa wiary w sercu pojedynczego człowieka, przez które przebiega linia walki pomiędzy dobrem a złem.

Wraz ze scholastyką średniowieczną (XII-XIII w.) teologia stała się nauką w sensie arystotelesowskim, dedukcyjnym, akcentującym dogmaty wiary i historia zbawienia, jako jej istotny przedmiot, stała się jedynie jej założeniem. Negatywnym skutkiem tego była utrata przez nią struktury narracyjnej a objawienie zaczęto interpretować w duchu metafizycznym ${ }^{8}$. „Niedorozwinięte pojęcie historyczności - twierdzi Balthasar - zahamowało nie tylko rozwój nauki o Kościele w czasach średniowiecza, ale również pozycję Kościoła wobec otaczającego świata", także tego niechrześcijańskiego.

W epoce nowożytnej, w której zaczęto akcentować praktyczny cel nauki w opanowaniu sił przyrody, zrodziła się wiara w naukowo-techniczny i cywilizacyjny postęp. Wskutek tego wiara nadprzyrodzona, od której wcześniej oczekiwano nie tylko zbawienia, ale i dóbr ziemskich utraconych wraz z utratą raju ziemskiego, została jakby ,przesunięta na inny poziom - poziom jedynie prywatny i pozaziemski - a równocześnie stała się w jakiś sposób nieistotna dla świata" ${ }^{10}$. Osłabiło to w dużej mierze jej wpływ na kształtowanie historii.

Od czasów Oświecenia - wskutek dominacji racjonalizmu - Objawienie chrześcijańskie było sprowadzane do wymiaru czysto historycznego i poddawane prawom racjonalizacji tworzącej się wówczas nauki historycznej i jej

${ }^{7}$ Karl Löwith, Historia powszechna i dzieje zbawienia. Teologiczne przestanki filozofii dziejów, tłum. J. Marzęcki (Kęty: Wydawnictwo ANTYK, 2002), 160-167.

${ }^{8}$ Carlo Greco, ,Rivelazione e Storia nella prospettiva del Concilio Vaticano II”, w Il Concilio venti anni dopo, t. I. L'ingresso della categoria della 'storia', red. E. Cattaneo (Roma: Editrice A.V.E, 1985), 121.

${ }^{9}$ Balthasar, Burzenie bastionów, 14-15.

${ }^{10}$ Benedykt XVI, Encyklika 'Spe salvi'. O nadziei chrześcijańskiej (Kraków: Wydawnictwo M, 2007), 17, 32. 
metodom. Racjonalizm i „filozofia historii” (Wolter), w której zaczął liczyć się jedynie człowiek oraz jego naturalne możliwości i cele, prowadziły do zeświecczenia historii. To myślenie miało wpływ na teologię, która wówczas oddaliła się od swej historycznej, biblijnej podstawy, w tym m.in. od idei przymierza i stała się „,doktryną wiary”, którą trzeba było racjonalnie uzasadniać i bronić. Wiara została w dużej mierze sprowadzona do wymiaru noetycznego, poznawczego. Większe znaczenie uzyskała wtedy apologetyka. Teologowie katoliccy musieli bronić wiarygodności objawienia Bożego wobec empirystów (deiści, encyklopedyści) negujących opisy cudów w nim zawarte. Szukali więc racjonalnych argumentów przemawiających za wiarygodnością cudów i proroctw jako ,zewnętrznych znaków” objawienia przydatnych do tego, by wiara była rozumiana i przeżywana jako ,posłuszeństwo zgodne z rozumem" (Rz 12,1). Wycofując się na pozycje obronne teologia nie była w stanie w sposób twórczy nawiązać dialogu z rodzącymi się wówczas dyscyplinami naukowymi i uczestniczyć w rozwoju konceptu nowożytnej racjonalności. Ten stan rzeczy w dużej mierze tłumaczy, dlaczego w dokumentach Soboru Watykańskiego I przeważała wizja atemporalna i esencjalna objawienia ${ }^{11}$, która przetrwała aż do odrodzenia się teologii historii w XX w.

Sens historii próbowała objaśniać od XIX w. filozofia historii inspirująca się myślą Hegla i Karola Marksa. Zdaniem Adama Schaffa, Marks - dokonując analizy społeczeństwa kapitalistycznego - odkrył obiektywne prawa rządzące historią i przekształcił ówczesną ,historiografię idealistyczną”, polegająca jedynie na opisie jednostkowych zjawisk w historiografię naukową uzasadnianą badaniami historycznymi na gruncie materializmu historycznego, czyli materialistycznego pojmowania dziejów ${ }^{12}$. Człowieka uznał jedynie za element „całokształtu stosunków społecznych”. Pojęcia heglowskiej teorii społeczeństwa: ,alienacja”, czyli pozostawanie w konflikcie z innymi ludźmi oraz „uprzedmiotowienie” człowieka i społeczeństwa uznał Marks za produkt kapitalizmu, a „rozwiązanie sprzeczności” widział w uświadomieniu sobie owej alienacji i w rewolucji socjalistycznej. Był przekonany, że przez przemiany społeczne dokonane metodą ,walki klas” ludzkość osiągnie wyzwolenie z niesprawiedliwości i ustanowi sprawiedliwy system społeczny, uzyska postęp zbiorowy i upragniony stan szczęścia. Marksizm jest przykładem wiary,

${ }^{11}$ Bartnik, Chrystus jako sens historii, 124.

12 Adam Schaff, Obiektywny charakter praw historii. Z zagadnień marksistowskiej metodologii historiografii (Warszawa: Państwowe Wydawnictwo Naukowe, 1955), 22. 
myślenia i organizowania życia społecznego „odbierającym Bogu sens historii i osoby"13.

To zeświecczone widzenie historii i wiara w postęp naukowo-techniczny w XIX i XX w. zastępowały w znacznej mierze religię. W odpowiedzi na zagrożenie ze strony marksizmu Kościół głosił wiarę w istnienie transcendentnego i osobowego Boga, od którego zależy byt człowieka i jego spełnienie się oraz prawdziwy sens historii ludzkiej.

Świadomość historycznego modelu wiary ujawniała się stopniowo. Jej początki związane są z odnowa biblijną, patrystyczną, liturgiczną i ekumeniczną w dobie przedsoborowej. Zwrot teologów ku Biblii był najpierw motywowany polemiką $\mathrm{z}$ racjonalizmem pozytywistycznym i z modernizmem (Loisy) i w tym celu odwoływali się oni do historii (problemy związane z chronologią wydarzeń, uwzględnienie Sitz im Leben, czyli kontekstu historycznego rekonstytuowanego dzięki badaniu źródeł historycznych, archeologicznych). Dopiero w latach czterdziestych XX w. zwrot ten zaowocował studiami naukowymi, które pomogły w głębszym rozumieniu słowa Bożego i w kształtowaniu wiary chrześcijańskiej ${ }^{14}$, w której świetle można pełniej odczytywać sens historii człowieka i ludzkości.

Należy tu wspomnieć także o wkładzie w teologię historii tzw. nouvelle theologie lat czterdziestych i pięćdziesiątych XX w. wypracowanej w dominikańskim centrum poszukiwań teologicznych w Le Saulchoir we Francji. Chenu, opierając się na postulatach A. Gardeila, postulował wówczas, by dokonać odnowy teologii przywracając w niej pierwszeństwo danym objawienia. We wcześniejszej metodzie dedukcyjnej tezy teologiczne były uzasadniane (probatur) według schematu: ex Scriptura, ex Traditione i ex ratione. W owym schemacie, według Chenu, dane objawienia służyły jedynie za zbiory argumentów i były podporządkowane rozumowo przyjętemu rozwiązaniu, podczas gdy powinny być uznane za źródło dla wiary Kościoła i służyć poznaniu tajemnic chrześcijańskich oraz odpowiedniemu urzeczywistnieniu historii. Dominikański uczony postulował także - w odróżnieniu od modernistów i antymodernistów katolickich - by status historyczny chrześcijaństwa uznać za konstytutywny, zakorzeniony $\mathrm{w}$ tajemnicy Wcielenia ${ }^{15}$. „Wiara nie jest

${ }^{13}$ Henri de Lubac, Ateizm i sens człowieka, tłum. O. Scherer (Paris: Éditions du Dialogue, 1969), 51.

${ }^{14}$ Roger Aubert, La teologie catholique au milieu du XX siècle (Tournai-Paris: Casterman, 1954), 11-23.

${ }^{15}$ Giuseppe Alberigo, „Cristianesimo come storia e teologia confessante”, w Marie-Domnique Chenu, Le Saulchoir. Una scuola di teologia (Casale Monferrato: Casa Editrice Marietti, 1982), XI. 
skażona przez to Wcielenie - pisał - tak samo jak Słowo nie zostało pomniejszone przez to, że stało się ciałem. Podwójne misterium teandryczne lub raczej jedyne misterium będące tajemnicą Chrystusa, w którym to, co boskie i to, co ludzkie stanowią jedno: jedyną Osobę, w którą wiara mnie wszczepia, Syna wiecznego Boga, który wszedł w historię"16.

\section{WIARA JAKO ODPOWIEDŹ NA HISTORYCZNE OBJAWIENIE BOŻE WEDEUG DEI VERBUM}

Prace przygotowawcze nad Konstytucją Dei Verbum pokazały, jak stopniowo na Soborze kształtowało się przekonanie o historycznej naturze objawienia. Schemat De depositio fidei pure custodiendo, czyli drugi dokument poprzedzający definitywny tekst Konstytucji dogmatycznej o Objawieniu Bo$\dot{z} y m^{17}$, określał objawienie jako „słowo”, tj. doktrynę, prawdę komunikowaną przez Boga człowiekowi, na którą ten winien odpowiedzieć wiarą ${ }^{18}$. Uzasadniał historyczny charakter objawienia tym, że: 1) dokonało się ono w kontekście historii zbawienia, rozumiejąc ją jako szereg wydarzeń zbawczych (longa illa series eventuum salutarium) kulminujących w życiu, śmierci i zmartwychwstaniu Chrystusa; 2) określone fakty (cuda, proroctwa, zmartwychwstanie Chrystusa, istnienie Kościoła), składając się na Objawienie, są pomocne w przyzwoleniu właściwym dla aktu wiary ${ }^{19}$. Choć w porównaniu z nauką Soboru Trydenckiego o objawieniu, w której nie ma nawet wzmianki o historii zbawienia i o szczegółowym sposobie przekazu objawienia, stanowi on postęp, z racji podtrzymania intelektualnego pojęcia objawienia, historia zbawienia jest w nim tak przeciwstawiona objawieniu, jak zwykłe fakty (mera facta) są przeciwstawione prawdom (veritates) wiary ${ }^{20}$. Intelektualistyczne

${ }^{16}$ Chenu, Le Saulchoir, 47.

${ }^{17}$ Pierwszym projektem był dokument: De duobus fontibus revelationis, opracowany przez Komisję Teologiczną w latach 1960-1962 i brak w nim było określenia pojęcia objawienia, jego natury i przedmiotu. Eugeniusz Florkowski, „Objawienie Boże według Konstytucji Dei Verbum", w Idee przewodnie soborowej Konstytucji o Bożym Objawieniu, red. Stanisław Grzybek (Kraków: Polskie Towarzystwo Teologiczne, 1968), 32-33.

${ }^{18}$ Sacrosanctum Oecumenicum Concilium Vaticanum Secundum, Schemata Constitutionum et decretorum de quibus disceptabitur in Concilii Sessionibus. Seria prima (Typis Polyglottis Vaticanis, 1962), IV, 28.

${ }^{19}$ Enrico Cattaneo, „La categoria 'storia' nel Vaticano II”, w Il Concilio venti anni dopo. 1. Ingresso della categoria 'storia' (Roma: Editrice A.V.E, 1985), 17.

${ }^{20}$ Cattaneo, „La categoria 'storia' nel Vaticano II”, 17. 
ujęcie objawienia jest skierowane przeciw modernistom i nie ma $\mathrm{w}$ nim mowy o dialogicznej, interpersonalnej i egzystencjalnej relacji. Modernizm zmierzał do dostosowania chrześcijaństwa do wymagań współczesnego myślenia i do postępu zawdzięczanego naukom, także historycznym, nie uniknął jednakże pokusy redukowania wiary, dogmatu do zakresu rozumowego, w którym kierował się założeniami i metodami pozytywizmu naukowego. Sprowadzał chrześcijaństwo do „faktów” historycznych; Chrystusa wiary przeciwstawiał Jezusowi historycznemu a natchnionemu Pismu Świętemu Biblię jako księgę jedynie ludzką. Ten błąd zauważył i z nim się rozprawiał m.in. Blondel, wskazując na nieuzasadnione oddzielanie historii od dogmatu przez modernistów i na konieczność tworzenia między nimi syntezy ${ }^{21}$.

Konstytucja Gaudium et spes mówi, że stworzony na obraz Boży człowiek, zniekształcony przez grzech i odnowiony przez Chrystusa, jest wplątany w historię, w której toczy się ciężka walka przeciw mocom ciemności, stąd też musi on się ciągle trudzić, aby wytrwać w dobrym i z pomocą łaski Bożej dojść do zjednoczenia z Bogiem i zostać odnowionym w swym człowieczeństwie (por. KDK 37). Bóg nie udziela człowiekowi łaski w sposób odległy, ale wkracza w jego historię, aby się mu w niej objawić. „Bóg niewidzialny (por. Kol 1,15; 1Tm 1,17) w nadmiarze swej miłości zwraca się do ludzi jak do przyjaciół (por. Wj 33,11; J 15,14-15) i obcuje z nimi (por. Bar 3,38 ), aby ich zaprosić do wspólnoty z sobą i przyjąć ich do niej” (KO 2). Bóg żywy, osobowy objawia się ludziom w Jezusie Chrystusie, Słowie Wcielonym, aby ich uczynić uczestnikami swego wewnętrznego życia, swej natury (Ef 2,18; 2P 1,4) (KO 2). Oczekuje od nich osobowej odpowiedzi wiary. Chodzi tu o podmiotowy wymiar objawienia o charakterze nadprzyrodzonym.

Dalej czytamy: „Ten plan objawienia urzeczywistnia się przez czyny i słowa wewnętrznie powiązane, tak że czyny dokonane przez Boga $\mathrm{w}$ historii zbawienia (historia salutis) ilustrują i umacniają naukę oraz sprawy słowami wyrażone; słowa zaś obwieszczają czyny i odsłaniają tajemnicę w nich zawartą" (KO 2). Jest to przedmiotowy wymiar objawienia, zawarty w depozycie wiary, czyli w Piśmie Świętym i Tradycji, określanymi „,najwyższym prawidłem wiary" (KO 21). Nie tylko to, co zawiera się w słowie Bożym - jak formułował to Sobór Watykański $\mathrm{I}^{22}$, ale ,czyny i słowa wewnętrznie ze

${ }^{21}$ Marco Ivaldo, "Aspetti della controversia Loisy-Blondel”, w Attualità del pensiero di Maurice Blondel, red. P. Henrici i in. (Milano: Editrice Massimo, 1975), 143.

${ }^{22}$ Constitutio dogmatica de fide catholica, Dei Filius, rozdz. III 28 w: Dokumenty Soborów Powszechnych. Tekst łaciński i polski, t. IV (1511-1870), oprac. A. Baron, H. Pietras (Kraków: Wydawnictwo WAM, 2005), 897-901. 
sobą powiązane" tworzą razem ,jedno wydarzenie objawienia"23. Słowa objawienia bez towarzyszących im czynów pozostają puste, jakby mniej wiarygodne. Czyny dokonane w historii zbawienia w powiązaniu ze słowami, które je objaśniają, mają również charakter rewelatywny. Dzięki temu historia, w której sytuują się słowa i czyny, nie jest już jedynie przedmiotem pośrednim objawienia, czy - jak uważano wcześniej - dowodem apologetycznym jakiejś prawdy objawionej ${ }^{24}$, ale staje się czymś wewnętrznym dla aktu objawienia - miejscem spotkania człowieka z Bogiem ${ }^{25}$. Potwierdza to dalsza wzmianka cytowanej Konstytucji mówiąca o objawieniu się Boga „słowami i czynami ludowi nabytemu [...] ażeby Izrael doświadczył, jakie są drogi Boże w stosunku do ludzi" (KO 14). Objawienie w tym szerszym rozumieniu jest procesem rozciągającym się w historii, w której Bóg w swej dobroci nie tylko zniża się do ludzi, ale i przekazuje im swe zbawcze plany, zasady postępowania itp., wzywając ich do kroczenia Jego „drogami”. Jego słowo cechuje się dynamiką działania, ,nie powraca do Niego bezowocne zanim nie [...] spełni pomyślnie swego posłannictwa" (Iz 55,11).

W czym wyraża się historyczna natura wiary w progresywnym rozwoju objawienia? Można ją dostrzec śledząc stopniową realizację przez Boga ekonomii zbawienia (oeconomia salutis) ${ }^{26}$ uwidaczniającej się najpierw w Starym (DV 14-16), a następnie w Nowym Testamencie (DV 17-20). W świetle Dei Verbum można wyodrębnić pewne etapy objawienia i korelatywnie historycznego rozwoju wiary: 1) ,trwałe świadectwo" Boga Stwórcy pozostawione w dziełach stworzonych (DV 3), na które człowiek powinien odpowiedzieć wiarą i wdzięcznością (Ps 136); 2) objawienie udzielone pierwszym rodzicom „na początku” historii (DV 3), które jednakże nie doprowadziło do ukształtowania się trwałej i wiernej relacji z Bogiem z powodu odwrócenia się człowieka od Niego przez grzech. Bóg jednak nie pozostawił wówczas człowieka

${ }^{23}$ Paul Hubert Schüngel, „Objawienie przez słowo”, Praktyczny słownik biblijny, tłum. T. Mieszkowski, P. Pachciarek, red. A. Grabner-Haider (Warszawa: Instytut Wydawniczy PAX, Wydawnictwo Księży Pallotynów, 1994), 853.

${ }^{24}$ Cattaneo, „La categoria 'storia' nel Vaticano II”, 18.

${ }^{25} \mathrm{O}$ historii zbawienia (historia salutis) Dei Verbum mówi jeden raz (nr 2).

${ }^{26}$ To pojęcie patrystyczne, niewystępujące w Biblii, wprowadzono ponownie na Soborze Watykańskim II, by uwydatnić historyczność chrześcijaństwa. Ekonomia zbawienia, w odróżnieniu od dawnej teologii mówiącej o „Bogu w sobie”, mówi o „Bogu dla nas” i oznacza Boski plan zbawienia ludzkości (Ef 1, 3-14) wywodzący się z woli Bożej, realizowany stopniowo $\mathrm{w}$ przestrzeni i czasie, czyli w historii zbawienia. Jej centrum stanowi Chrystus, Józef Kudasiewicz, „Biblia Księgą zbawienia”, w Biblia o odkupieniu, red. R. Rubinkiewicz SDB (Lublin: RW KUL, 2000), 22-24. 
samemu sobie, ale „otworzył mu drogę do zbawienia” (Rdz 3,15; DV 3), zamierzając je urzeczywistnić w pełni czasów w Jezusie Chrystusie. Ufna i pełna wiary modlitwa o uzyskanie przebaczenia i zbawienia będzie odtąd pewnym znamieniem doświadczenia duchowego Izraelitów (Ps 51); 3) objawienie się Boga narodowi izraelskiemu za pośrednictwem patriarchów i proroków począwszy od Abrahama, któremu Bóg przekazał obietnicę, iż stanie się ojcem wielu narodów ( $\operatorname{Rdz} 12,2 ; 15,5)$, Mojżesza, przez którego wyprowadził lud izraelski z niewoli egipskiej i uczynił go wolnym narodem zawierając $\mathrm{z}$ nim przymierze ( $\mathrm{Wj} 3,15 ; 19-20)$. Stąd też w Izraelu wiara będzie ukazywana jako postulat wynikający z zawartego przymierza ${ }^{27}$.

Objawienie Starego Przymierza było ukierunkowane na Chrystusa (por. Hbr 1,1), który „przez całą swoją obecność i okazanie się przez słowa i czyny, przez znaki i cuda, zwłaszcza zaś przez śmierć swoją i pełne chwały zmartwychwstanie, a wreszcie przez zesłanie Ducha Prawdy, objawienie doprowadził do końca i do doskonałości (revelationem complendo perficit)" (KO 4). Jezus Chrystus, jako wysłannik Ojca, jest pośrednikiem, a jako objawiający Go w swym człowieczeństwie jest pełnią Objawienia. Objawienie w Jezusie Chrystusie, słowie Wcielonym i Wydarzeniu zyskuje szczególne bogactwo wyrazu prawdy Bożej w wymiarze podmiotowym i przedmiotowym. Jezus oczekiwał od słuchających Go wiary w prawdę, którą usłyszał od Ojca (J J 8,40) i w zbawcze czyny, których dokonywał (J 10,25), potwierdzając je cudami: ,[...] niewidomi wzrok odzyskują, chromi chodzą [...]” (Łk 7,22). Wiara według Dei Verbum nie odnosi się więc do idei, prawd abstrakcyjnych, ale do „Prawdy osobowej, która pojawiła się w historii, działała w historii i stamtąd nadaje kierunek dziejom"28.

Ewangelia, którą Chrystus głosi (Evangelium Christi) i poleca apostołom, aby ją przekazywali wszystkim narodom (Mt 28,18), staje się w ich ustach Ewangelią o Chrystusie (Evangelium de Christo) przyjmowaną z wiarą przez coraz to nowych uczniów ${ }^{29}$. Jest ona w dalszym ciągu żywym słowem o Nim, dzięki temu, że Duch Święty, Paraklet prowadzi apostołów, ich następców i cały Kościół do pełni prawdy o Bogu i zbawieniu człowieka w Chrystusie (J 16,13) - ujawniającej się pełniej dopiero w świetle uwielbie-

27 Jacques Dupont, „Wiara”, w Stownik teologii biblijnej, tłum. K. Romaniuk, red. X. Léon-Dufour (Poznań-Warszawa: Pallottinum, 1973), 1026.

${ }^{28}$ Henri de Lubac, Stowo Boże w historii człowieka. Objawienie Boże, tłum. B. Czarnomska (Kraków: Cerf-Kairos; Wydawnictwo M; ZNAK, 1997), 43.

${ }^{29}$ Georges Chantraine, „'Dei Verbum'. Un enseignement et une tache”, Nouvelle Revue Théologique 107(1985): 835. 
nia Go przez Ojca w misterium paschalnym - ożywia wiarę ludu Bożego i poucza wewnętrznie jego członków o sposobie moralnego i duchowego postępowania drogą Chrystusową. Duch jest Tym, który ożywia Tradycję wywodzącą się od Apostołów (traditio ab apostolis) tak, iż może się ona, dzięki przepowiadaniu Ewangelii przez pasterzy Kościoła, rozwijać i wzrastać, gdy chodzi o rozumienie objawienia, kontemplację tajemnic Bożych, dociekanie przez wiernych prawdy wiary $\mathrm{w}$ sobie $\mathrm{i}$ w relacji do osobistego życia oraz doświadczalne pojmowanie spraw duchowych (KO 8).

„Bogu objawiającemu się należy okazać posłuszeństwo wiary (por Rz 16, 26; por. Rz 1,5; 2Kor 10,5-6), poprzez które człowiek z wolnej woli cały powierza się Bogu, okazując 'pełną uległość rozumu i woli wobec Boga objawiającego' i dobrowolnie uznając objawienie przez Niego dane" (KO 5). Lubac podkreśla, że „zarówno objawienie Boże przyniesione przez Chrystusa, jak i wiara, którą na nie odpowiadamy, stanowi fundamentalną część składową Kościoła" ${ }^{30}$. Tylko wtedy, gdy na to historyczne objawienie, czyli objawienie dokonane w dziejach Starego i Nowego Przymierza zostanie udzielona odpowiedź wiary, ,zakorzenia się" ono w postawie człowieka i doświadcza on zbawienia. Historyczne judeochrześcijańskie objawienie, przyjęte i zinterpretowane przez Kościół, jest streszczone w wielu prawdach wiary (fides quae), stanowiących pewien system prawd, odpowiedź zaś udzielona Bogu na nie i powierzenie się $\mathrm{Mu}$ w Duchu Świętym składa się na podmiotowy wymiar wiary (fides qua). Odpowiedź ta, według Dei Verbum, winna być wyrazem idącej za poznaniem woli i wolności człowieka, jego całościowego zaangażowania się po uświadomieniu sobie wezwania pochodzącego od objawiającego się Boga, Jego dobroci i miłości, a nie jedynie „powinnością”, jak twierdziła Konstytucja Dei Filius ${ }^{31}$, choć o tej odpowiedzi jest powiedziane w Dei Verbum, że ,jest należna” Bogu i że można jej udzielić jedynie dzięki łasce Bożej. Z porównania nauki Dei Verbum na temat aktu wiary z tym, co czytamy o wierze w Dei Filius, wynika że w tym wcześniejszym dokumencie, wskutek tego, że powtarza on naukę z Sacrosancta Soboru Trydenckiego ${ }^{32}$ odnośnie do określenia treści objawienia i natury aktu wiary ${ }^{33}$ - chodzi o naukę bardziej apologetyczną i intelektualną w sensie akcentowania tego

${ }^{30}$ Lubac, Stowo Boże $w$ historii człowieka, 79.

${ }^{31}$ Konstytucja Dei Filius, rozdz. III, 28.

${ }^{32}$ Sessio IV (sub Paulo III). Recipitur libri sacri et traditiones apoostolorum, 1, w Dokumenty Soborów Powszechnych. Tekst łaciński i polski, t. IV (1511-1870): 210-212.

33 Por. Ghislain Lafont, „La Constitution 'Dei Verbum' et ses précédents conciliaires”, Nouvelle Revue Théologique 110(1988): 60. 
elementu w akcie wiary. Dei Verbum daje wyraźnie do zrozumienia, że prawdy objawione nie są prawdami abstrakcyjnymi, ale są składowymi Bożego planu zbawienia ludzkości.

\section{WAŻNOŚĆ HISTORYCZNEGO WYMIARU TEOLOGII I WIARY DLA KSZTAETOWANIA HISTORII I ESCHATOLOGICZNEGO SPEŁNIENIA STWORZENIA}

Sobór Watykański II był „darem Ducha” i „proroctwem” dla Kościoła oraz świata i w dalszym ciągu ,pozostaje wydarzeniem o fundamentalnym znaczeniu, które pozwala nie tylko zrozumieć historię Kościoła w ostatnim stuleciu, ale także - i przede wszystkim - upewnić się o nieustannej obecności Zmartwychwstałego u boku Oblubienicy, dzielącej doświadczenia tego świata" - stwierdził Jan Paweł II $^{34}$. Kościół Chrystusowy, pielgrzymujący do Królestwa Ojca, czuje się W dalszym ciągu ,zespolony z rodzajem ludzkim i jego historią, dlatego też winien uczestniczyć w pomyślnych i niepomyślnych doświadczeniach ludzi żyjących w świecie i dzielić się z nimi orędziem zbawienia (KDK 1).

„Kościół z biegiem wieków dąży stale do pełni prawdy Bożej, aż wypełnią się w nim słowa Boże” (KO 8). To „coraz pełniejsze uczestnictwo w prawdzie Bożej” oznacza „wzbogacenie wiary” zarówno pod względem jej treści (znaczenie obiektywne) jak jej świadomości u wiernych (znaczenie podmiotowe $)^{35}$. Owo ,wzbogacenie wiary kard. Wojtyła uznawał za zasadniczy postulat realizacji duszpasterskiego celu Vaticanum II.

\subsection{Wewnętrzny związek teologii i wiary chrześcijańskiej z historią ludzką i możliwość jej kształtowania}

Objawienie, przyjęte wiarą, jest źródłem dla wiedzy teologicznej, której wskazania mają znaczenie dla historii ludzkiej, dla tego jak należy wierzyć i jak według wiary postępować.

Ponowne odkrycie biblijnego i historycznego wymiaru teologii i wiary w latach trzydziestych XX w. we Francji i pogłębienie go w dokumentach soborowych uwolniło w dużej mierze teologię od neoscholastyki skupiającej

\footnotetext{
${ }^{34}$ Jan Paweł II, „Przemówienie do uczestników Konferencji na temat realizacji nauczania Powszechnego Soboru Watykańskiego II" (27 II 2000), w Michalik, Odkryć Sobór, 161.

${ }^{35}$ Karol Wojtyła, U podstaw odnowy. Studium o realizacji Vaticanum II (Kraków: Polskie Towarzystwo Teologiczne, 1972), 11, 14.
} 
się na metafizycznych tezach o boskim Absolucie i zwróciło ją ku rzeczywistości ludzkiej, konkretnej, ku światu i temu, czym on żyje. Gaudium et spes domaga się, by teologia uwzględniała badania podejmowane przez historię i przez to stawała się nauką historyczną nawet w spekulatywnym zgłębianiu właściwego dla niej przedmiotu (KDK 62). Nie powinna ona zaniedbywać związku z teraźniejszością, przez co stanie się bardziej pożyteczna dla duszpasterstwa, ewangelizacji, formacji postaw moralnych i duchowych.

Teologia posoborowa stała się teologia wydarzenia, wewnętrzną prawdą realnego wydarzenia odkrywaną w świetle wiary chrześcijańskiej, mogącego mieć wpływ na inne wydarzenia historii. Chodzi tu zarówno o wydarzenia zawarte w judeochrześcijańskim objawieniu, o Wydarzenie Jezus-Chrystus, które nie należy tylko do przeszłości, ale jest aktualne, teraźniejsze dla człowieka dzisiejszego, jak i te pojawiające się w aktualnie dziejącej się historii odczytywane w świetle tych pierwszych ${ }^{36}$.

Chrześcijaństwo opiera się na wierze w to, że Bóg chce zbawienia wszystkich ludzi $(1 \mathrm{Tm} 2,4)$, dlatego też nie tylko historia poszczególnych osób wierzących, ale cała historia ludzka, poczynając od przyjścia Chrystusa, stanowi dzieje zbawienia. Chrześcijańska wiara łączy się z historią, ponieważ jest wiarą w zbawcze działanie Boga uwidaczniające się na różne sposoby na przestrzeni historii Izraela oraz historii ludzkiej $(\mathrm{Hbr} 1,1)$ kształtowanej przez Kościół.

Najbardziej wewnętrzny związek wiary chrześcijańskiej z historią ludzką ujawnia się w tym, że w centrum jednej i drugiej znajduje się Jezus Chrystus. Jako Syn Boży, posłany przez Ojca, wszedł On przez swe wcielenie w historię świata, przez swe życie wypełnione głoszeniem Królestwa Bożego i jego podstawowego przykazania - miłości Boga i bliźniego, a zwłaszcza przez swą mękę, śmierć i zmartwychwstanie wyzwolił wszystkich z niewoli grzechu i wysłużył im łaskę przybranego synostwa Bożego (Rz 8,15). Dlatego ,jeden jest Pan dziejów ludzkich (historiae humanae) i dziejów zbawienia (historiae salutis)" - podaje Gaudium et spes (41), dokonując rozróżnienia pomiędzy jedna a drugą historią i zarazem łącząc je w jedną historię w Chrystusie.

Kościół zmierza do tego, aby Wydarzenie Jezus-Chrystus było uznane przez człowieka za centrum także jego osobistej historii, gdyż Syn Boży przez swe wcielenie ,zjednoczył się jakoś z każdym człowiekiem” (KDK 22), a dzięki temu, że ofiarował swe życie za wszystkich i że został wskrzeszony

${ }^{36}$ Angelo Scola, „Wydarzenie Jezusa Chrystusa dzisiaj”, w Chrystus - Zbawiciel, Communio 17(1997): 13. 
przez Ojca mocą Ducha Świętego, a następnie wywyższony i ustanowiony Panem chwały - „może człowiekowi przez Ducha swego udzielić światła i sił, aby zdolny był odpowiedzieć najwyższemu swemu powołaniu" (KDK 10). Należy dodać za Gaudium et spes, że ostateczne powołanie tak chrześcijanina, jak i każdego człowieka jest jedno - boskie (22).

Wiara chrześcijańska ma zdolność kształtowania historii ludzkiej i nadawania jej moralnego i duchowego sensu, ukierunkowania człowieka i tego, co czyni, na Boga. Chodzi tu nie tylko o wiarę opartą na tradycji duchowej Kościoła, ale przede wszystkim o wiarę czerpaną na bieżąco z medytacji słowa Bożego, z katechezy, z przepowiadanej tajemnicy Chrystusa i z uczestnictwa w uobecnianej zbawczej ofierze Chrystusa w Eucharystii, o wiarę będącą darem Ducha Świętego uświęcającego Kościół (Rz 5,5) i rozświetlającego drogi historii. Postępująca laicyzacja i dramatyczne aspekty historii skłoniły Kościół na początku XXI w. do ponownego zaakcentowania ważności słowa Bożego w jego życiu i misji wobec świata (XII Zwyczajne Zgromadzenie Ogólne Synodu Biskupów (5-26 X 2008 r.). Słowo Boże jest racją [Kościoła] w tych dwóch względach i dlatego konieczne jest ciągłe poznawanie go i życie nim tak, by nauczanie Kościoła zostało uznane w świecie za wiarygodne ${ }^{37}$.

Poznaniu słowa Bożego służą zwłaszcza egzegeza i teologia. W badaniu tekstów biblijnych egzegeza - obok historyczno-krytycznej metody niezbędnej dla objaśnienia historycznych wydarzeń - powinna: a) uwzględniać ich wymiar teologiczny, ,czytać i interpretować Pismo Święte w tym samym Duchu, w jakim zostało napisane" (DV 12) oraz pamiętać o jedności całego Pisma; b) czerpać z żywej tradycji całego Kościoła, której źródłem i inspiratorem jest Duch Święty; c) nie pomijać analogii wiary, czyli reguł rozumienia wiary, które uzyskują swoją pełnię sensu w chrystologii ${ }^{38}$. Jedynie oparcie się na hermeneutyce wiary pozwala tak interpretować Pismo Święte, by było ono źródłem prawdy i życia dla całego Kościoła i by ukazywało zbawcze działanie Boga w historii.

Przyjmując jedność Pisma Świętego, która nie oznacza uznania jakościowej ciagłości między Starym i Nowym Testamentem, tak jakoby ten drugi Testament był jedynie prostą kontynuacją pierwszego, chrześcijańska teologia

37 Benedykt XVI, „Homilia (5 października 2008). Bez Boga człowiek jest samotny, a społeczeństwo zagubione", L'Ossevatore Romano 29(2008), 12: 9.

${ }^{38}$ Benedykt XVI, „Egzegeza nie tylko historyczna, ale i teologiczna”, 14 X - XIV Kongregacja, L'Osservatore Romano 29(2008), 12: 34; Tenże, Jezus z Nazaretu, część I. Od chrztu w Jordanie do Przemienienia, tłum. W. Szymona (Kraków: Wydawnictwo M, 2007), 8-9. 
i wiara winny poszukiwać głębszego poznania historii zbawienia, w tym historii Jezusa Chrystusa i historyczno-społecznego gruntu swego zakorzenienia w Starym Testamencie, o czym - w imię czystości wiary i trzymania się ,istoty” Nowego Testamentu - niekiedy zapominano ${ }^{39}$. Zwłaszcza teologiczna wizja historii w ujęciu św. Pawła jest głęboko zakorzeniona w Starym Testamencie i prezentuje nierozerwalną jedność dziejów zbawienia w całej ich rozciągłości (Ga 3,6; Rz 9-11).

Jak ukazał Gerhard von Rad, wiara Izraela „oparta na wydarzeniach historycznych i stale przekształcana zgodnie ze zmieniającą się sytuacja” - pod wpływem ingerencji Boga - ,jest ugruntowana w teologii historii”, dla której punktem wyjściowym są akty objawiającego się Boga, a przedmiotem materialnym - prawdy wiary odnoszące się do Jahwe i spisane świadectwa wiary ${ }^{40}$. Profetyczne tradycje Izraela mają charakter odrębny od dawnych czynów Jahwe, gdyż głoszą, zapowiedziane wcześniej ,nowe rzeczy” (Iz 43,18-19), tj. nowe czyny za pomocą których Bóg dokona zbawienia w przyszłości ${ }^{41}$. Zdaniem Lohfinga, historię Izraela należy rozumieć nie tylko linearnie z nastawieniem na przyszłość, ale także zgodnie $\mathrm{z}$ obecną $\mathrm{w}$ niej 'zasadą powtórzeń', gdyż każde pokolenie Izraela (historia linearna) w nawiązaniu do faktu wyjścia ludu izraelskiego z Egiptu, może w duchu wiary podczas świąt paschalnych powrócić do tamtego wydarzenia i niejako wziąć w nim udział, gdy - zgodnie z podanym rytuałem - zabije baranka i spożyje go (zasada powtórzeń). Wówczas zrozumie swą teraźniejszość w perspektywie wydarzenia zbawczego z przeszłości. W typologicznie rozumianej historii izraelskiej ,,przeszłość i przyszłość odpowiadają sobie nawzajem"42. To rozumienie historii jest pomocne dla katolickiej teologii liturgii i dla wiary chrześcijańskiej. To, o czym mówi historia, że dokonało się jeden raz, to że historia zbawienia mówi, iż Jezus Chrystus jako arcykapłan ,złożywszy raz na zawsze jedną ofiarę za grzechy, zasiadł po prawicy Boga” (Hbr 10,12), to sakrament odnawia (renovat) przez celebrację eucharystyczną wiele razy; historia przypomina to wydarzenie zbawcze, a liturgia sprawia, że przeszłość nie jest zapomniana, nie w tym sensie, że miałaby się na nowo dokonać (non faciendo),

${ }^{39}$ Georges Chantraine, „Eschatologia i historia zbawienia”, Communio [Nadzieja i eschatologia] 4(1984): 53.

${ }^{40}$ Wilfrid Harrington, Teologia biblijna, tłum. J. Marzęcki (Warszawa: Instytut Wydawniczy PAX, 1977), 67.

41 Tamże, 72-75.

42 Norbert Lohfing, Pieśń Chwaty, tłum. J. Doktór (Warszawa: Instytut Wydawniczy PAX, 1982), 132-134. 
ale w tym znaczeniu, że się ją celebruje (sed celebrando) ${ }^{43}$, że - jak się aktualnie objaśnia - misterium zbawcze się uobecnia. W liturgii ważna jest 'zasada powtarzania' rozumiana jako uobecnianie w Eucharystii tego, co wydarzyło się w tajemnicy wcielenia i odkupienia ${ }^{44}$ i czerpanie stąd światła i mocy na drodze wiary ku przyszłości, ku paruzji Chrystusa, w której chrześcijanie upatrują kres historii.

Zakładając owo fundamentalne doświadczenie religijne z prehistorii Izraela (por. Wj 6,4-8), Bruno Forte w swej teologii historii objaśnia judeochrześcijańską wiarę jako „ruch wyjściowy (esodale) serca i jako powierzenie siebie" Bogu, który przychodzi (avviene) i się objawia" ${ }^{45}$. Ma na myśli „objawienie", które jest udzielane człowiekowi przez Ducha Świętego, aby mógł pełniej zrozumieć obiektywne objawienie i urzeczywistnić jego wskazania w swym życiu, w historii. Jego zdaniem, akt wiary wymaga zawsze od człowieka transcendentnego otwarcia ducha, wyjścia ze swojej konkretnej aktualnej sytuacji historycznej ku Bogu, który przychodzi, objawia się przez swoje wcielone Słowo. Akt ten prowadzi do spotkania (incontro) z Bogiem w Chrystusie, w którym, jak w symbolu, to co boskie i ludzkie łączy się w jedno ${ }^{46}$. Ten ,exodalny i adwentowy” model wiary i teologii, jak go określa teolog z Neapolu, uwzględnia konkretną historyczność. Nadaje się więc do zgłębiania sensu historii ludzkiej i przeżywania jej w duchu wychodzenia $\mathrm{z}$ siebie i poszukiwania właściwego kierunku rozwoju - własnego życia i historii z uwzględnieniem dynamiki historycznej pochodzącej z nadziei na paruzję Chrystusa i spotkanie z Nim. Zdaniem Theobalda, akt wiary i samo chrześcijaństwo współczesne koniecznie potrzebują odniesienia do historii biblijnej, do „biblijnego projektu wiary”, i istotnych prawd (zapowiedzi mesjańskie) i norm moralnych (przykazania) z nią związanych i wymagają zarazem reinterpretacji w świetle współczesnej kultury, aby mogły kształtować chrześcijańską tożsamość ${ }^{47}$.

${ }^{43}$ S. Augustinus, Sermo 220: PL 38, 1089.

${ }^{44}$ Lohfing, Pieśń Chwaty, 135.

${ }^{45}$ Bruno Forte, La teologia come compagnia, memoria e profezia. Introduzione al senso e al metodo della teologia come storia (Milano: Edizioni San Paolo, 1996), 57.

${ }^{46}$ Bruno Forte, La Parola della fede. Introduzione alla Simbolica ecclesiale (Milano: Edizioni San Paolo, 1996), 42.

${ }^{47}$ Christoph Theobald, ,Seguendo le orme ...” della Dei Verbum. Bibbia, teologia e pratiche di lettura (Bologna: Edizioni Dehoniane di Bologna, 2011), 11-120. 


\subsection{Wiara i chrześcijański kierunek kształtowania historii świata}

Konstytucja Gaudium et spes ukazuje świat jako stworzony przez Boga, dobry i przeznaczony do tego, by po upadku grzechowym i odkupieniu przez Chrystusa, „doznał przemiany i doszedł do pełni doskonałości” (KDK 2) ${ }^{48}$. W owym świecie, ,widowni historii rodzaju ludzkiego”, w toczącej się jego historii Kościół ma pełnić zbawczą misję. Ma głosić powszechne powołanie do braterstwa w Jezusie Chrystusie i przypominać, że objawiony w Nim Bóg jest Ojcem wszystkich ludzi (KDK 92). Ma prowadzić wszystkich do zbawienia i służyć odnowie poszczególnych społeczeństw (KDK 3).

Urzeczywistnienie ewangelicznego stylu życia w świecie napotyka na duże trudności, gdyż nie brak jest w nim wrogości i konfliktów, które człowiek wznieca i bywa ich ofiarą (KDK 8). Zwłaszcza od czasu hekatomby Żydów - Auschwitz stawiane jest pytanie o rezultaty wiary w Europie po dwu tysiącach lat od początków jej ewangelizacji. Nie można w nie zupełnie wątpić, skoro to samo stulecie „było naznaczone jakimś szczególnym działaniem Boga" bogatego w miłosierdzie, a także i dobrem czynionym przez człowieka, które „wyznaczają miarę złu” w dziejach człowieka" ${ }^{49}$ Także XX wiek zrodził wielu świętych i męczenników. W historii ludzkiej dochodzi niejednokrotnie do zderzenia się dobra ze złem i na tle tego drugiego pierwsze jeszcze bardziej ujawnia się w swej mocy (Rz 5,20).

Działanie Boga w historii nie jest prowadzone z pozycji siły, nie jest ono konkurencyjne względem działania ludzkiego, ale jest naznaczone poszanowaniem godności i wolności człowieka, miłością i przyjaźnią. Wzorując cię na nim i poddając się mu człowiek powinien, z pomocą Bożą, zdobywać się na analogiczne działanie wobec innych.

$\mathrm{Na}$ obecnym etapie dziejów ujawniają się różne tendencje kulturowe i duchowe określane jako postmodernistyczne: relatywizm poznawczy i moralny; zwątpienie w naukowo-techniczny rozwój i w postęp historii, w który wcześniej wierzono i łączono $\mathrm{z}$ nim nadzieję na większą wolność i szczęśliwe życie; nihilizm „sprowadzający każdą wartość do rangi wymiany” (A. del Noce); ekstremalny materializm jako styl życia, konsumizm wynikający z wygenerowania nowych potrzeb i oferowania nowych dóbr materialnych; naturalizm skłaniający człowieka do zdania się na własne instynkty i poszukiwania

48 Antonio Cannizzo, „Quattro concetti giovannei. In margine al dibattito sulla Gaudium et spes", w Il Concilio venti anni dopo. 3. Il rapporto Chiesa-mondo (Roma: Editrice A.V.E., 1986), 109.

49 Jan Paweł II, Pamięć i tożsamość (Kraków: Wydawnictwo ZNAK, 2005), 57, 24. 
na tej płaszczyźnie autorealizacji negując prawo Boże i nie licząc się z obiektywnym dobrem własnym (zdrowie) i wspólnym (małżeństwo, rodzina, przyszłość społeczeństwa). Tendencje te są wynikiem rozczarowania wartościami czasów nowożytnych i głoszonymi wówczas „nowymi wartościami”, które obecnie uznaje się nierzadko za „mity”. Sprowadzają one człowieka do sfery immanentnej, sfery potrzeb materialnych i skłaniają go do wtopienia się w kulturę typu instant, gasząc w jego sercu pragnienie wartości wyższych, duchowych, Boga. Przyczyniają się do kwestionowania prawd wiary i do relatywizowania ewangelicznych zasad moralności ${ }^{50}$.

Obok tych tendencji w wielu rejonach świata można zaobserwować tragiczne kontrasty społeczno-ekonomiczne i nowe, niespotykane dotąd formy ubóstwa, biedy wynikające $\mathrm{z}$ nieopanowanej chciwości pieniądza i władzy jako źródeł wszelkiego zła. Ubodzy pragną wyzwolenia z trudnej sytuacji i przemiany ich świata na lepszy. Według teologa historii, Brunona Forte, teologia aktualna winna interesować się nie tylko postępem cywilizacyjnym, kulturowym dokonującym się w świecie, ale także „drugą, [negatywną] stroną historii" i nieść wyzwalające i zbawcze przesłanie w Jezusie Chrystusie tym, którzy go potrzebują. Działania na rzecz sprawiedliwości i rozwoju człowieka nie są wstępem do ewangelizacji, ale są integralną jej częścią i służą pozytywnej ,transformacji historii, w której panowanie Boga jest już obecne, choć jeszcze niedostatecznie urzeczywistnione" ${ }^{, 51}$.

Ponadto zadaniem Kościoła jest badanie różnych zjawisk społecznych, „znaków czasu” i odróżnianie tego, co w historii ludzkiej jest zgodne z postulatami i z obecnością Królestwa Bożego od tego, co jest im przeciwne (KDK 44). Teologowie są wezwani do analizowania w sposób krytyczny nowych nurtów myślenia w świecie wskazujących na ewentualny kryzys wartości religijnych i rozeznawania stanu nowych ruchów religijnych w Kościele, czuwania nad zachowaniem wierności tradycji apostolskiej i pomagania wiernym we właściwym rozumieniu zmysłu wiary (sensum fidelium) ${ }^{52}$. Wraz z duszpasterzami i świeckimi powinni rozeznawać wymienione zjawiska w wierze, gdyż ta „rozjaśnia wszystko nowym światłem i ujawnia Boży za-

${ }^{50}$ Wojciech Wójtowicz, „Współczesne zagrożenia według kardynała Josepha Ratzingera”, Studia Koszalińsko-Kotobrzeskie 10(2005): 238-251.

51 Gerhard Müller, Ubóstwo i godność człowieka, tłum. S. Śledziewski (Sandomierz: Wydawnictwo Diecezjalne i Drukarnia, 2015), 155.

${ }^{52}$ Federazione Intelectuale delle Università Cattoliche, La posta in gioco. Memoria del Concilio e futuro della Chiesa nella riflessione di teologi dei cinque continenti, red. M. Lamberigts i in. (Bologna, 2016), 122. 
mysł odnośnie do pełnego powołania człowieka; dlatego kieruje ona umysł do rozwiązań w pełni ludzkich" (KDK 11).

Powołanie chrześcijańskie zawiera w sobie i urealnia powołanie ludzkie, gdyż człowiek stworzony przez Boga z miłości, został ukierunkowany ontycznie na swego Stwórcę i wezwany do naśladowania Chrystusa, w którym jaśnieje pełnia człowieczeństwa. Dlatego przyjęcie Chrystusa z wiarą i życie w Duchu Świętym nie jest nadbudową nad człowieczeństwem, ale sposobem życia, które prowadzi człowieka grzesznego do przemiany i do zjednoczenia z Bogiem owocując odnowionym człowieczeństwem. „Osoba ludzka [...] ma być zbawiona, a ludzkie społeczeństwo odnowione" (KDK 3), podkreśla Sobór, dając do zrozumienia, że człowiek w zakresie indywidualnym i społecznym jest celem misji Kościoła. A to oznacza, że w teologii historii i w jej ostatecznej fazie, jaką jest eschatologia, winna być uwzględniona antropologiczno-teologiczna przesłanka.

Według dynamicznej soborowej antropologii, zawartej w zarysie w Gaudium et spes, człowiek jest istotą, która staje się w historii, realizuje się w swym chrześcijańskim powołaniu i w swym rozwoju ludzkim, osobowym. Ojcowie Soborowi ukazali integralną wizję człowieka jako bytu cielesno-duchowego, społecznego, żyjącego w określonym miejscu i czasie, otwartego na transcendencję, na Boga. Podstawa dla niej jest nie tylko jego rozumność, wolność, zdolność do miłości i sumienie (KDK 15-17), ale także fakt, iż czuje się on ,nieograniczony w swych pragnieniach i [jest] powołany do wyższego życia” (KDK 10), którego jednak nie jest w stanie osiągnąć o własnych siłach, gdyż jako grzeszny upada i doznaje rozdarcia w samym sobie. Pomimo tego jest ,nieustannie pobudzany przez Ducha Bożego i nigdy nie będzie zupełnie obojętny na problemy religijne [...] bowiem zawsze będzie pragnął wiedzieć, choćby nawet niejasno, jaki jest sens jego życia, działalności i śmierci” (KDK 41). Na te wszystkie pytania homo religiosus może znaleźć pełną sensu odpowiedź w Chrystusie, którego ziemskie życie było włączone w historię ludzką i przez nią było kształtowane, a od Jego misterium paschalnego stało się historiotwórcze i nadające ex post sens życiu wszystkich ludzi ${ }^{53}$. Dlatego słusznie podkreślono, iż „Pan [zmartwychwstały] jest celem ludzkich dziejów, punktem do którego zwracają się pragnienia historii oraz cywilizacji, ośrodkiem rodzaju ludzkiego, weselem wszystkich serc i pełnią ich pożądań” (KDK 45).

${ }^{53}$ Hans Urs von Balthasar, Teologia dziejów, Zarys, tłum. J. Zychowicz (Kraków: Wydawnictwo ZNAK, 1996), 73. 


\subsection{Wartość zaangażowania doczesnego dla eschatologicznego spełnienia się stworzenia}

Skoro Jezus Chrystus jest transcendentnym celem człowieka i celem ludzkich dziejów, jaki jest sens działalności ludzkiej w historii i jak mają się jej skutki do wieczności? Chodzi tu o działalność chrześcijanina jako obywatela „państwa ziemskiego”, podejmowaną w duchu wiary, która ujawnia swą coraz większą dojrzałość w miłości (Ga 5,6), w uczynkach miłości.

Najpierw należy zauważyć, że działanie człowieka oraz oczekiwane przez niego owoce zderzają się $\mathrm{w}$ jego świadomości z tym, co go ogranicza, a zwłaszcza z grzechem, którego „narzędziem” może się stać to, co czyni. Zamiast służyć prawdziwemu dobru osoby ludzkiej, dobru wspólnemu, jego wytwory moga zostać skierowane przeciw niemu samemu (KDK 37). Dlatego historia ludzka jest stale miejscem walki przeciw mocom ciemności i człowiek ciągle potrzebuje oczyszczenia w słowie Bożym i w sakramentach Kościoła z pychy i z pożądliwości, aby jego sposób działania mógł być udoskonalony. Nowy sposób działania uzyskuje on ucząc się od Chrystusa i trwając w uległości Jego Duchowi, będąc przekonanym, iż prawem przekształcenia świata i prawdziwego postępu jest ,nowe przykazanie” (KDK 38), miłość, która domaga się wzięcia na siebie krzyża trudów i obowiązków.

Ponadto człowiek wraz ze swoimi planami przyszłości i ze swym działaniem musi zmierzyć się z kwestią śmierci, która rodzi w nim lęk przed unicestwieniem jego bytu i jego działania. Wszystkie jego wysiłki i zdobycze techniczne nie są w stanie go od niej wyzwolić, a jedynie o jakiś czas ją opóźnić. Jest na nią ciągle narażony, jak przekonuje to wszystkich obecny czas pandemii spowodowanej koronawirusem. Mysterium mortis człowiek może głębiej pojąć i pokonać lęk przed nią, gdy z wiarą przylgnie do Chrystusa, zmartwychwstałego Pana, zwycięzcy śmierci (1Kor 15,57). Wymownym przykładem takiej postawy są męczennicy, którzy w akcie męczeństwa, przyjętym heroiczną wiarą, transcendują doczesną płaszczyznę dziejową i osiągają płaszczyznę pozaczasową, eschatologiczną, w której otwiera się przed nimi ${ }^{54}$ - nowe niebo i nowa ziemia (Ap 21,1), nowa historia w Bogu i z Bogiem.

W podobny, choć nie aż tak radykalny sposób relatywizują doczesną płaszczyznę dziejową mnisi, gdy wyrzekaja się świata i jego dóbr, także tych godziwych i odnoszą zwycięstwo nad potrójną pożądliwością: ciała, czyli

${ }^{54}$ Fidel F. Gonzalez, „Męczeństwo, pamięć o świętych i problemy związane z beatyfikacją-kanonizacją męczenników", tłum. L. Balter, w Męczennicy XX wieku (Kolekcja Communio 14) (Poznań: Pallottinum, 2001), 414. 
zmysłowością; oczu, czyli urokiem pozorów; pychą życia, czyli pychą wynikającą z posiadanego bogactwa (1J 2,16). Wydaje się, że owa relatywizacja straciła na sile wraz z otwarciem się Kościoła na świat w dobie Soboru Watykańskiego II i większego włączenia zakonników w misję Kościoła wobec świata. Nie negując wartości związanych z płciowością, samodzielnym decydowaniem o sobie i uzasadnionym dysponowaniem dobrami materialnymi, osoby konsekrowane są wezwane do prowadzenia życia, w którym wobec kultury hedonistycznej ukażą świadectwo czystości ewangelicznej, wobec postaw materialistycznych, immanentnych zwrócą uwagę na pierwszeństwo Boga i dóbr przyszłych, wobec złego używania wolności w świecie ukażą posłuszeństwo Bogu i Jego woli ${ }^{55}$. Dzięki temu świadectwu „charakterystyczne przymioty Jezusa - dziewictwo, ubóstwo i posłuszeństwo - stają się w pewien swoisty i trwały sposób «widzialne»w świecie, a spojrzenie wiernych zwraca się ku tajemnicy Królestwa Bożego, które już jest obecne w historii, ale w pełni urzeczywistni się w niebie" (VC 1).

W zupełnie inny sposób uczestniczą w historii świata ludzie świeccy, których zadaniem, z racji ich powołania, jest ,szukać Królestwa Bożego zajmując się sprawami świeckimi i kierując nimi po myśli Bożej” (KK 31). Bycie powołanym do świata i pozostawanie w nim oraz uświęcanie go ,na kształt zaczynu od wewnątrz" (KK 31) składają się na charakter świecki (indoles secularis) laikatu i mają wpływ na kształtowanie jego tożsamości. Od Vaticanum II należy ową tożsamość postrzegać jako włączoną w misję Kościoła w świecie widzianym pozytywnie ${ }^{56}$ i uznanym w jego prawach i wartościach zapewniających mu istnienie i rozwój, które człowiek ma stopniowo poznawać i respektować. W świetle duchowości świeckich aktywność ludzka odpowiada zamysłowi Bożemu i wyraża się w realizacji otrzymanego od Stwórcy polecenia, by czynić sobie ziemię poddaną ( $\operatorname{Rdz} 1,28 ; 9,2-3)$. Nie chodzi tu o sakralizację działalności człowieka, ale jedynie o „odniesienie” jej do Boga Stwórcy i Jego przykazań, jak i o odniesienie siebie samego oraz całej rzeczywistości doczesnej z różnymi jej zakresami (rodzina, polityka, gospodarka, kultura), a przez to także o moralne jej uporządkowanie (KDK 34). Gaudium et spes akcentuje dwojaki cel działalności ludzkiej: a) podmiotowy, czyli samego człowieka i jego integralny rozwój; b) przedmiotowy,

\footnotetext{
55 Jan Paweł II, Adhortacja 'Vita consecrata', nr 85-92( Ząbki: Apostolicum, 1996), 153-163.

${ }^{56}$ Przedsoborowa wizja Kościoła była bardzo zhierarchizowana i cechowała się opozycją wobec świata i potwierdzaniem swej niezależności od władzy świeckiej. W tej optyce świeckość nie była rozpoznana w jej prawach i wartościach. Georges Chantraine, Laikat. Chrześcijanie w świecie, tłum. K. Domagalski (Warszawa: Pallottinum, 1993), 21.
} 
czyli wykonywane przez niego dzieła służące postępowi cywilizacyjnemu i wyjaśnia, że „normą aktywności ludzkiej jest to, żeby zgodnie z planem Bożym i wolą Bożą odpowiadać prawdziwemu dobru rodzaju ludzkiego i pozwolić człowiekowi na realizowanie i wypełnianie pełnego swojego powołania bądź indywidualnie, bądź społecznie" (KDK 35).

Rozłam między wiarą a życiem codziennym wskazuje na to, że rola zaangażowania ziemskiego i sposób realizacji chrześcijańskiego powołania nie są pojmowane jednakowo zobowiązująco, co skutkuje zajmowaniem niewłaściwych postaw moralnych wobec zadań doczesnych. Jedni, wychodząc z założenia, że skoro „nie mamy tutaj trwałego miasta, ale szukamy tego, które ma przyjść" (Hbr 13,14), sądzą, że człowiek może zaniedbać swoje obowiązki ziemskie. Drudzy, ulegając nadmiernej aktywności podejmowanej w świecie w celu wzbogacenia się, osiągnięcia sukcesu itp., tak pogrążają się w sprawach ziemskich, że praktyki religijne stają się dla nich jedynie czymś formalnym, odizolowanym od życia, osobistej i bieżącej historii (KDK 43). Dlatego też pierwsi powinni zaangażować się w budowanie „państwa ziemskiego”, bo nadzieja życia wiecznego nie zwalnia chrześcijanina od realizacji przykazania miłości bliźniego. Drudzy winni przyjąć i realizować nakaz Boży przekazany pierwszym rodzicom $(\operatorname{Rdz} 1,28)$ i uczyć się wykonywać swą pracę w duchu uczestnictwa w dziele Stwórcy oraz w tajemnicy paschalnej Chrystusa (Mt 16,24), ofiarując Bogu w Eucharystii trud swej pracy. Ideałem jest tu ,synteza życiowa”, do której prowadzi ,życie łaski przeżywane w zadaniach ziemskich" i zadania ziemskie pełnione w duchu uległości woli Boga i Jego łasce stanowiącej dla nich jakby „ożywiającą krew”57. Oznacza ona twórczy udział chrześcijan w kształtowaniu historii.

Czy zaangażowanie w budowanie ,państwa ziemskiego”, według zamysłu Bożego, będzie miało wpływ na królestwo Boże przychodzące w Chrystusie u kresu historii doczesnej i na uczestnictwo człowieka w nim, czy też będzie ono czymś zupełnie nowym? Od początku kształtowania się teologii rzeczywistości ziemskich i eschatologii XX wieku można tu mówić o pewnej ewolucji w postrzeganiu relacji historii do Królestwa Bożego.

Przed Soborem, w latach pięćdziesiątych, znana była „eschatologia kreatywna" Metza głosząca inkarnacjonizm, czyli wcielenie Słowa Bożego jako początek ery eschatologicznej, akcentująca wielką, aktywną wartość nadziei chrześcijańskiej. „Nadzieja ta, ukierunkowana na przyszłość wiary chrześci-

${ }^{57}$ Giuseppe Lazzatti, Świeccy a chrześcijańskie zaangażowanie w sprawy doczesne, tłum. Z. Ziółkowski (Warszawa: Instytut Wydawniczy PAX, 1988), 100. 
jańskiej, nie może się zrealizować nie interesując się światem i jego przyszłością” - pisał tenże teolog - ale „powinna przyjąć odpowiedzialność za jedyną przyszłość obiecaną" przez Boga ${ }^{58}$. Mniej więcej w tym samym czasie inni teologowie podkreślali potrzebę większego włączenia się Kościoła, np. poprzez księży robotników w środowisko świata i uznania pewnych elementów kultury, a także ich absorpcji przez Kościół celem ulepszenia przekazu tajemnic wiary; nadzieja na zbawienie miałaby tu obejmować - obok dóbr niebieskich - także dokonania człowieka zrealizowane pod wpływem łaski Chrystusa wcielającej się w historię świata, antycypujące w jakimś sensie przyszłe ujawnienie się królestwa Bożego (M.I. Montuclard) ${ }^{59}$. Z kolei Teilhard de Chardin głosił autotranscendencję historii osiąganą w ogólnym procesie ewolucji przed wcieleniem Słowa Bożego i po nim. Jego zdaniem „Chrystus czeka ze swoim drugim i ostatecznym przyjściem, aż społeczność ludzka, wyczerpawszy całkowicie swe możliwości 'przyrodzone', stanie się w końcu zdolna przyjąć od Niego spełnienie nadprzyrodzone"60. Według tej „wizji” nadzieja nie ma dwóch przedmiotów, Boga i efektów ludzkich działań, ale tylko jeden: Ducha Bożego działającego w ludzkich poczynaniach, poprzez które przygotowywane są coraz lepsze warunki do ujawnienia się, za sprawą Boga, Królestwa niebieskiego ${ }^{61}$.

Wypowiedzi Ojców Vaticanum II nie są gloryfikacją postępu materialnego i cywilizacyjnego, który określili ,wielkim dobrem” i zarazem czymś niosącym ze sobą „olbrzymią pokusę”, np. troski jedynie o własne sprawy a nie o innych (KDK 37). Oto dlaczego aktywność ludzka wymaga dogłębnej przemiany mocą łaski Chrystusa, by mogła stać się „tworzywem Królestwa niebieskiego" (KDK 38). Działanie, dokonywane $\mathrm{z}$ wiarą we wcielenie Boga w historii i z miłością do innych, nie okaże się daremne, gdyż jego „owoce [...] odnajdziemy potem [w Królestwie niebieskim] na nowo, ale oczyszczone ze wszystkiego brudu, rozświetlone i przemienione" (KDK 39).

Posoborową relację pomiędzy historią a Królestwem Bożym można określić umiarkowanym eschatologizmem, reprezentowanym m. in. przez Y. Congara i von Balthasara. Teolog szwajcarski uważa, że trudno jest mówić o postępie w historii świętej, jaką jest historia odkupienia świata przez Chrystusa

58 Johann Baptista Metz, Sulla teologia del mondo (Brescia: Queriniana, 1974), 88.

${ }^{59}$ Carlo Molari, „La storia della teologia cattolica postconciliare”, w Il Concilio venti anni dopo. 1. L'ingresso della categoria 'storia' (Roma: Editrice A.V.E., 1985), 62-63.

${ }^{60}$ Pierre Teilhard de Chardin, Zarys wszechświata personalistycznego $i$ inne pisma, tłum. M. Tazbir, K. Waloszczyk (Warszawa: Instytut Wydawniczy PAX, 1985), 200.

61 Molari, „La storia della teologia cattolica postconciliare”, 63-64. 
i obecności w nim Kościoła, gdyż definitywnego stanu Królestwa Bożego nie da się zrealizować tak w duszy ludzkiej, jak i w historii świata i w jego strukturach społecznych, nawet działaniem wspomaganym łaską Ducha, ponieważ działanie to, choć ujawnia wartość pozytywną, wymaga integracji z ostatecznym porządkiem zaprowadzonym przez Boga ${ }^{62}$. „Dzieje mają swój immanentny eidos, ale od kiedy Chrystus, który zstąpił do otchłani a następnie wstąpił do nieba i siedzi po prawicy Ojca, zabrał go ze sobą, mogą one ostatecznie tam go odnaleźć”,63.

\section{WNIOSKI KOŃCOWE}

Na podstawie przeprowadzonej analizy związku teologii i wiary z historią zbawienia i historią świecką nasuwają się następujące spostrzeżenia i wnioski:

1. Odkrycie historycznego wymiaru wiary chrześcijańskiej $w$ teologii w XX w. pod wpływem impulsów zewnętrznych (nauki nowożytne, personalizm) oraz wewnętrznych (np. odnowa biblijna) obudziło w Kościele katolickim świadomość, że chrześcijaństwo nie jest religią abstrakcyjną zdominowaną neoscholastyką, ale religią objawioną, konkretną, zanurzoną w rzeczywistość tego świata i w jego historię, która się ciągle dzieje.

2. Historyczny wymiar teologii i wiary ujawnił się bardzo wyraźnie w Konstytucji o Ojawieniu Bożym Dei Verbum ukazującej, iż historia: a) jest miejscem objawienia Boga przez fakt dobrowolnej Jego ingerencji w nią; b) jest treścią i przedmiotem objawienia Bożego, gdyż obejmuje wzajemnie powiązane ze sobą wydarzenia zbawcze i słowa Boga skierowane do wybranych osób i do ludu izraelskiego. Owej historycznej naturze objawienia Bożego odpowiada historyczny wymiar, czy też charakter wiary, będącej odpowiedzią udzielaną Bogu (fides qua) na Jego słowa, obietnice, wymagania (fides quae). $\mathrm{Z}$ wiary przeżywanej i z historii świętej, sytuującej się w historii świeckiej, rodzi się teologia jako refleksja nad nimi.

3. Biblijna historia zbawienia jako historia relacji Boga z ludem izraelskim i owego ludu z Bogiem - oparta na obietnicach Bożych i na ich spełnieniu, na przymierzu - ma charakter dynamiczny, rozwojowy i osiąga swoją pełnię w Wydarzeniu Jezus-Chrystus i w Nowym Przymierzu. Jako Słowo, które

${ }^{62}$ Hans Urs von Balthasar, Luigi Giussani, Miejsce chrześcijanina w świecie, tłum. K. Kubis, A. Porębski (Kraków: Wydawnictwo WAM, 2003), 89-100.

${ }^{63}$ Balthasar, Teologia dziejów, 126. 
stało się ciałem $(\mathrm{J}$ 1,14) i jako Ten, który dokonał odkupienia rodzaju ludzkiego i został ustanowiony Panem chwały, Jezus Chrystus jest zawsze żyjacym, Alfą i Omegą historii, współczesnym względem każdego człowieka i każdego pokolenia ludzkich dziejów świata. Prawda ta sytuuje chrystologię w centrum historii jako historii zbawienia i wyznacza jej istotną rolę $w$ jej interpretacji. Owa zaś chrystologia jest ważna dla teologii duchowości interesującej się nie tylko osobistym uświęceniem człowieka, ale i jego chrześcijańskim i ludzkim urzeczywistnieniem się w historii.

4. Soborowe ujęcie historii, będące efektem przezwyciężenia wcześniej zakładanego dualizmu pomiędzy porządkiem nadprzyrodzonym obejmującym zbawienie pojedynczych osób a porządkiem natury, do którego zaliczano życie społeczne i toczącą się historię ludzkości, jest ujęciem dynamicznym i rozwojowym. Według niego wszyscy ludzie, z racji bycia stworzonymi na obraz Boży, mają do wypełnienia jedno powołanie - boskie, i mogą je urzeczywistnić idąc za głosem Boga w swym sumieniu, angażując się w budowanie wspólnoty braterskiej, w pomnażanie dobra wspólnego oraz akceptując trudności życiowe, cierpienia itp., poprzez które Duch Święty stwarza każdemu człowiekowi możliwość uczestnictwa w tajemnicy Chrystusa, jedynego i powszechnego Zbawiciela świata. Dynamika historii poddanej Duchowi ujawnia się na poszczególnych jej etapach rozwoju i prowadzi do wyzwolenia człowieka od różnego rodzaju zła, do odnowy społeczeństwa i ostatecznie do zbawienia w Chrystusie. Chrześcijanie upatrują kierunek i spełnienie rozwoju historii ludzkiej w Chrystusie Zbawicielu, Bogu i Człowieku doskonałym, objawiającym pełną prawdę o Bogu i o człowieku oraz jego moralno-duchowym i ludzkim spełnieniu się osobistym i społecznym; udzielającym człowiekowi w słowie Bożym i w sakramentach Kościoła mocy Ducha do realizacji powołania.

5. Chrześcijański wkład w budowę „państwa ziemskiego” i w kształtowanie historii ludzkiej znamionuje się szczególnym charakterem, gdyż czerpie on sens życia i działania, nadzieję nieśmiertelności i moc do zaangażowania się w wypełnienie zadań doczesnych z Chrystusa, Pana historii. Świadomość przemijania tego świata (1 Kor 7,31) i oczekiwanie na „nowe niebo i nową ziemię" (Ap 21,1) nie osłabiają chrześcijańskiego zaangażowania w doczesności pełnionego w duchu miłości bliźniego i służby z nadzieją, że istotne owoce tego zaangażowania staną się elementem, „tworzywem” przyszłego królestwa Bożego będącego niezasłużonym darem Stwórcy i Zbawiciela. Antropologia, chrystologia, teologia biblijna, teologia rzeczywistości ziemskich i eschatologia XX w. rzucają dużo światła na sposób kształtowania historii jako historii zbawienia i na sposób rozumienia i przeżywania jej zarówno w środkowej, jak i w ostatniej fazie. 


\section{BIBLIOGRAFIA}

Alberigo, Giuseppe. „Cristianesimo come storia e teologia confessante”, Nota introduttiva, in Marie- Dominique Chenu, Le Saulchoir. Una scuola di teologia. IX-XXX. Casale Monferrato: Casa Editrice Marietti, 1982.

Aubert, Roger. La teologie catholique au milieu du XX siècle. Tournai-Paris: Casterman, 1954. Augustinus. Quest. in Hept. 2, 73: PL 34, 623.

Augustinus. Sermo 220: PL 38, 1089.

Balthasar, Hans Urs von. Burzenie bastionów, tłum. Jerzy Zakrzewski. Kraków: Wydawnictwo WAM, 2000.

Balthasar, Hans Urs von, Giussani, Luigi. Miejsce chrześcijanina w świecie, tłum. Katarzyna Kubis, Andrzej Porębski. Kraków: Wydawnictwo WAM, 2003.

Balthasar, Hans Urs von. Teologia dziejów. Zarys, tłum. Juliusz Zychowicz. Kraków: Wydawnictwo ZNAK, 1996.

Bartnik, Czesław Stanisław. Chrystus jako sens historii. Wrocław: Wydawnictwo Wrocławskiej Księgarni Archidiecezjalnej, 1987.

Bartnik, Czesław Stanisław. Historia ludzka i Chrystus. Szkice z chrześcijańskiej wizji dziejów. Katowice: Księgarnia św. Jacka, 1987.

Benedykt XVI. „Egzegeza nie tylko historyczna ale i teologiczna”, 14 X - XIV Kongregacja. L'Osservatore Romano 29(2008): 34-35.

Benedykt XVI. Encyklika „Spe salvi”. O nadziei chrześcijańskiej. Kraków: Wydawnictwo M, 2007.

Benedykt XVI. Homilia (5 października 2008). „Bez Boga człowiek jest samotny, a społeczeństwo zagubione". L'Osservatore Romano 29(2008): 7-9.

Benedykt XVI. Jezus z Nazaretu. Część I. Od chrztu w Jordanie do Przemienienia, tłum. Wiesław Szymona. Kraków: Wydawnictwo M, 2007.

Cannizzo, Antonio. „Quattro concetti giovannei. In margine al dibattito sulla Gaudium et spes”. W Il Concilio venti anni dopo. 3. Il rapporto Chiesa-mondo, red. Nunzio Galantino, 106115. Roma: Editrice A.V.E., 1986.

Cattaneo, Enrico. „La categoria 'storia' nel Vaticano II”. W Il Concilio venti anni dopo. 1. Ingresso della categoria 'storia', a cura di Enrico Cattaneo, 11-32. Roma: Editrice A.V.E., 1985.

Chantraine, Georges. „'Dei Verbum'. Un enseignement et une tache”. Nouvelle Revue Théologique 107(1985): 823-837.

Chantraine, Georges. „Eschatologia i historia zbawienia”. Nadzieja i eschatologia. Com 4(1984): 37-54.

Chantraine, Georges. Laikat. Chrześcijanie w świecie, tłum. Kazimierz Domagalski. Warszawa: Pallottinum, 1993.

Chenu, Marie-Dominique. Le Saulchoir. Una scuola di teologia. Casale Monferrato: Casa Editrice Marietti, 1982.

Congar, Yves. Chrystus i zbawienie świata, tłum. Anna Turowiczowa. Kraków: Wydawnictwo ZNAK, 1968.

Dokumenty Soborów Powszechnych. Tekst łaciński i polski, t. IV (1511-1870), oprac. Arkadiusz Baron, Henryk Pietras. Kraków: Wydawnictwo WAM, 2005.

DUDEN Deutsches Universalwörterbuch, hrsg. Günther Drosdowski i in. Mannheim-Wien-Zürich: Dudenverlag, 1983.

Dupont, Jacques. „Wiara”. W Stownik teologii biblijnej, tłum. Kazimierz Romaniuk, red. Xavier, Léon-Dufour, 1025-1034. Poznań-Warszawa: Pallottinum, 1973. 
Federazione Intelectuale delle Università Cattoliche. La posta in gioco. Memoria del Concilio e futuro della Chiesa nella riflessione di teologi dei cinque continenti, a cura di Mathijs Lamberigts i in. Bologna: Edizioni Dehoniane, 2016.

Fédou, Michel. „Le Concile Vatican II: un enjeu d'interpretation”, W Vatican II sous le regard des historiens, red. Christoph Theobald, 137-157. Bologna: Edizioni Dehomiane Bologna, 2006.

Florkowski, Eugeniusz. „Objawienie Boże według Konstytucji Dei Verbum”. W Idee przewodnie soborowej Konstytucji o Bożym Objawieniu, red. Stanisław Grzybek, 31-43. Kraków: Polskie Towarzystwo Teologiczne, 1968.

Forte, Bruno. La Parola della fede. Introduzione alla Simbolica ecclesiale.Milano: Edizioni San Paolo, 1996.

Forte, Bruno. La teologia come compagnia, memoria e profezia. Introduzione al senso e al metodo della teologia come storia. Milano: Edizioni San Paolo, 1996.

Gonzalez, Fidel F. „Męczeństwo, pamięć o świętych i problemy związane z beatyfikacją-kanonizacją męczenników”, tłum. Lucjan Balter. W Męczennicy XX wieku (Kolekcja Communio 14), 80-151. Poznań: Pallottinum, 2001.

Greco, Carlo. „Rivelazione e Storia nella prospettiva del Concilio Vaticano II”. W Il Concilio venti anni dopo, t. I. L'ingresso della categoria della 'storia', red. Enrico Cattaneo, 117128. Roma: Editrice A.V.E., 1985.

Harrington, Wilfrid. Teologia biblijna, tłum. Józef Marzęcki. Warszawa: Instytut Wydawniczy PAX, 1977.

Ivaldo, Marco. “Aspetti della controversia Loisy-Blondel”. W Attualità del pensiero di Maurice Blondel, red. Peter Henrici i in., 138-145. Milano: Editrice Massimo, 1975.

Jan Paweł II. Adhortacja apostolska „Vita consecrata”. Ząbki: Apostolicum, 1996.

Jan Paweł II. Pamięć i tożsamość. Kraków: Wydawnictwo ZNAK, 2005.

Jan Paweł II. „Przemówienie do uczestników Konferencji na temat realizacji nauczania Powszechnego Soboru Watykańskiego II" (27 II 2000). W Andrzej Michalik, Odkryć Sobór. Szkic historyczno-teologiczny Soboru Watykańskiego II, 161-167. Tarnów: Wydawnictwo BIBLOS, 2006.

Jan XXIII. „Gaudete Mater Ecclesia. Przemówienie wygłoszone w dniu otwarcia Soboru Watykańskiego II" (11 X 1962). W Andrzej Michalik, Odkryć Sobór. Szkic historyczno-teologiczny Soboru Watykańskiego II, 120-131. Tarnów: Wydawnictwo BIBLOS, 2006.

Kudasiewicz, Józef. „Biblia Księgą zbawienia”. W Biblia o odkupieniu, red. R. Rubinkiewicz SDB, 7-40. Lublin: RW KUL, 2000.

Lafont, Ghislain. „La Constitution 'Dei Verbum' et ses précédents conciliaires”. Nouvelle Revue Théologique 110(1988): 58-73.

Lazzatti, Giuseppe. Świeccy a chrześcijańskie zaangażowanie w sprawy doczesne, tłum. Zenon Ziółkowski. Warszawa: Instytut Wydawniczy PAX, 1988.

Lohfing, Norbert. Pieśń Chwały, tłum. Jan Doktór. Warszawa: Instytut Wydawniczy PAX, 1982.

Löwith, Karl. Historia powszechna i dzieje zbawienia. Teologiczne przestanki filozofii dziejów, tłum. Józef Marzęcki. Kęty: Wydawnictwo ANTYK, 2002.

Lubac, Henri de. Ateizm i sens człowieka, tłum. Olga Scherer. Paris: Éditions du Dialogue, 1969.

Lubac, Henri de. Słowo Boże w historii człowieka. Objawienie Boże, tłum. Beata Czarnomska. Kraków: Cerf-Kairos; Wydawnictwo M; ZNAK, 1997.

Metz, Johann Baptist. Sulla teologia del mondo. Brescia: Queriniana, 1974.

Molari, Carlo. „La storia della teologia cattolica postconciliare”. W Il Concilio venti anni dopo. 1. L'ingresso della categoria 'storia', 35-68. Roma: Editrice A.V.E., 1985. 
Müller, Gerhard Ludwig. Ubóstwo i godność człowieka, tłum. Sławomir Śledziewski. Sandomierz: Wydawnictwo Diecezjalne i Drukarnia, 2015.

Sacrosanctum Oecumenicum Concilium Vaticanum Secundum. Schemata Constitutionum et decretorum de quibus disceptabitur in Concilii Sessionibus. Seria prima. Typis Polyglottis Vaticanis, 1962.

Schaff, Adam. Obiektywny charakter praw historii. Z zagadnień marksistowskiej metodologii historiografii. Warszawa: Państwowe Wydawnictwo Naukowe, 1955.

Schüngel, Paul Hubert. „Objawienie przez słowo”. W Praktyczny stownik biblijny, tłum. Tadeusz Mieszkowski, Paweł Pachciarek, red. Anton Grabner-Haider, 853. Warszawa: Instytut Wydawniczy PAX; Wydawnictwo Księży Pallotynów, 1994.

Scola, Angelo „Wydarzenie Jezusa Chrystusa dzisiaj”. W Chrystus - Zbawiciel. Communio 17(1997): 10-32.

Teilhard de Chardin, Pierre. Zarys wszechświata personalistycznego $i$ inne pisma, tłum. Mieczysław Tazbir, Konrad Waloszczyk. Warszawa: Instytut Wydawniczy PAX, 1985.

Theobald, Christoph. 'Seguendo le orme ...' della Dei Verbum. Bibbia, teologia e pratiche di lettura. Bologna: Edizioni Dehoniane, 2011.

Wójtowicz, Wojciech. „Współczesne zagrożenia według kardynała Josepha Ratzingera”. Studia Koszalińsko-Kołobrzeskie 10(2005): 237-258.

Wojtyła, Karol. U podstaw odnowy. Studium o realizacji Vaticanum II. Kraków: Polskie Towarzystwo Teologiczne, 1972.

Zuberbier, Andrzej. „Wstęp”. W Balthasar Hans Urs von. Teologia dziejów. Zarys, tłum. Juliusz Zychowicz, 5-16. Kraków: Wydawnictwo ZNAK, 1996.

\title{
KONIECZNOŚĆ ZACHOWANIA ZWIAZZKU TEOLOGII I WIARY Z HISTORIA W DUCHU SOBORU WATYKAŃSKIEGO II
}

\author{
St re s z c z e n i e
}

Artykuł wskazuje na konieczność zachowania związku teologii i wiary z historią i pogłębiania go dzisiaj z tego względu, że pewne czynniki z przeszłości (racjonalizm, neoscholastyka) osłabiają go, a niektóre współczesne tendencje (postmodernizm, teologia abstrakcyjna, relatywizm religijny) podważają jego sens. Autor wychodzi od związku teologii i wiary z historią zbawienia w starożytności, wskazuje na osłabienie go w średniowieczu, zerwanie go w dobie Oświecenia i ponowne odkrycie jego ważności w początkach XX w. Analizując Konstytucję o Objawieniu Bożym Dei Verbum, przybliża zawartą w niej wykładnię wiary (fides quae i fides qua) jako odpowiedzi na objawienie Boga w historii. Uwzględniając następnie soborowe i posoborowe wyzwania teologiczne i duszpasterskie, akcentuje ważność zachowania wewnętrznego związku teologii i wiary z historią dla kształtowania tej drugiej poprzez aktywność ludzką odpowiadającą dobru wspólnemu i realizacji ostatecznego powołania chrześcijanina. Wskazuje na możliwość kształtowania dziejów w powiązaniu z tajemnicą zbawczego wcielenia i zawartą w owym kształtowaniu dialektyką, a następnie objaśnia sposób eschatologicznego spełnienia stworzenia i jego związek z zaangażowaniem w doczesności.

Słowa kluczowe: Objawienie Boże; wiara; historia zbawienia; laicyzacja historii; zaangażowanie doczesne; postęp; dialektyka postawy; owoce wysiłków. 